\title{
Formation of United Local Communities: Conditions and Problematic Issues
}

Modern Ukraine is in serious economic and political difficulties. One of the reasons is the ineffectiveness of the existing public administration system as well as its administrative and territorial structure. Reforming the country requires significant changes that should be aimed at the establishment of an open political system as well as the development of civil society and the growth of each individual citizen's welfare.

The reform of local government and territorial organisation of power based on decentralisation, the conceptual basis of which was approved in 2014, with its practical implementation in early 2015, has proved to be among the most effective and significant of the declared policy reforms in our country ${ }^{2}$. The decentralisation reform is aimed at establishing a modern system of local government in Ukraine based on European values of local democracy development, vesting local communities with powers and resources that will ensure local economic growth and providing the citizens with high-quality and affordable public services.

The role of united local communities (ULCs) in ensuring the interests of citizens in all areas of daily life in any respective territory should become central. The positive results achieved in the implementation of the decentralisation reform are to a large extent due to special attention paid to it by top officials and authorities in the state. In particular, the decentralisation reform was constantly in the field of vision of the President of Ukraine. According to the Decree of the President of Ukraine on highpriority measures for the development of local government in Ukraine for

1 Yuliia Dorokhina, Doctor of Sciences of Law, Associate professor, V. I. Vernadskyi Taurian National University.

2 On the approval of the Concept of reforming local government and territorial organisation of power in Ukraine: Order of the Cabinet of Ministers of Ukraine of 1 April 2014, № 333-p, Official website of the Verkhovna Rada of Ukraine (Electronic address), http://zakon4.rada.gov.ua/laws/show/333-2014-\%D1\%80. 
$2017^{3}$, the rise of institutional capability of local government is determined as a priority of state development for 2017. In September 2016, the Cabinet of Ministers of Ukraine approved a new edition of the action plan for the implementation of the concept of reforming local government and territorial organisation of power in Ukraine by its order ${ }^{4}$. The basic measures provide for the development of conceptual grounds of field reforms in education, health care, social security as well as the improvement of legislative and regulatory support of reforms, reinforcement of the responsibility of local government bodies for their decisions, carrying out information and explanatory work and, last but not least, consultative and methodological support of local communities. In April 2017, the Government adopted its Order on the approval of the medium-term plan of priority actions of the Government by 2020 and the plan of priority actions of the Government for $2017^{5}$. In the medium-term aspect, the decentralisation reform has been identified as one of the key priorities in shaping a system of effective governance in the state. Thus, a medium-term directional map of the reform has been adopted, which enables communities to plan both their budget and development not for a year, but in the long term. The mediumterm plan provides for $100 \%$ consolidation of basic-level local councils into capable local communities by 2020 .

The decentralisation reform has received quite broad support from the public and expert milieus. Moreover, the highest support for the reform was recorded in the regions that are the leaders in the formation of united local communities.

The practical implementation of the process of local community consolidation began in mid-2015, thus, at present we can analyse the results of two years of the work. In 2015, 159 united local communities that consolidated 793 local communities were formed. On 25 October 2015, new local government bodies were elected in these communities, from 1 January 2016, they switched to direct budget settlements with the State Treasury and, according to the results of 2016, they showed a significantly positive dynamics of their development. These communities received

3 On immediate measures to develop local government in Ukraine for 2017: Decree of the President of Ukraine on 7 December 2016, № 545/2016, Official website of the Verkhovna Rada of Ukraine (Electronic source) - Information source: http:// zakon3.rada.gov.ua/laws/show/545/2016.

4 Some questions on the implementation of the Concept of reforming local government and territorial organisation of power in Ukraine: Order of the Cabinet of Ministers of Ukraine of 22 September 2016, № 688-p, Government's website (Electronic source) - Information source: http://www.kmu.gov.ua/control/ru/cardnpd?docid $=249350402$.

5 On the approval of a medium-term plan of priority actions of the Government by 2020 and plan of priority actions of the Government of 3 April 2017, № 275-p, Government source (Electronic source) - Information source: http://www.kmu.gov.ua/ control/uk/cardnpd?docid $=249935442$. 
extended powers and additional resources that allowed them to implement infrastructure development projects: to repair and even build schools, kindergartens, water pipes, roads, street lighting systems; purchase utility equipment; create utility companies, take care of landscaping, etc.

In 2016, there was significant progress in the formation of the united local communities -as their number increased 2.3 times. As of 2017, there were 366 ULCs in Ukraine that consolidated 1740 local councils in which the first local elections were held. In 2017, these communities switched to direct inter-budget relations with the State Budget of Ukraine. In 2016, the process of election of the elders in villages and towns of the united communities began. In 2017, following the adoption of a number of laws resolving the problematic issues related to the consolidation, the process of ULC formation received a new impulse. On 30 April 2017, the first local elections took place in 47 other ULCs. As of the end of 2017, 413 ULCs were formed in Ukraine that consolidated 5,258 settlements, in which the first elections of local government bodies took place.

The practical process of the formation of united local communities constantly reveals problematic issues that require legislative or normative regulation. Thus, in 2016, the Cabinet of Ministers of Ukraine adopted a Resolution on amendments to the methodology for the formation of capable local communities ${ }^{6}$, which regulated the issue of making changes to long-term plans for the formation of the territories of communities in regions, the submission of such changes to the Government's consideration as well as the official confirmation of the composition of united local communities included in the relevant long-term plan. In 2017, significant improvements in the process of legislative regulation of the formation of capable local communities took place:

- Act on amendments to certain legislative acts of Ukraine on voluntary adhesion of local communities ${ }^{7}$ was adopted, which introduced a procedure for voluntary adhesion to already established ULCs and specified requirements for the recognition of ULC capability. The act should facilitate the formation of ULCs in accordance with approved long-term plans, since it provides that if the ULC council refuses to accept the adhesion of another local community to the ULC, on its own initiative, the Cabinet of Ministers of Ukraine may revoke its resolution recognising such community as capable;

6 On amendments to the methodology for the formation of capable local communities: Resolution of the Cabinet of Ministers of Ukraine of 8 September 2016, № 601, Government's website (Electronic source) - Information source: http://www.kmu.gov. $\mathrm{ua} /$ control/uk/cardnpd?docid=249308591.

7 On amendments to certain legislative acts of Ukraine on voluntary adhesion of local communities: Act of 9 February 2017, № 1851-VIII, Official website of the Verkhovna Rada of Ukraine (Electronic source) - Information source: http://zakon2.rada. gov.ua/laws/show/1851-19. 
- Act on amendments to certain legislative acts of Ukraine on the peculiarities of the voluntary consolidation of local communities located in neighbouring areas $^{8}$ was adopted. The law introduced a mechanism for the creation of ULCs, which included local communities of neighbouring administrative districts and the possibility of creating ULCs, the centre of which being a city of regional significance, as well as determined the procedure for the first local elections in such ULCs;

- Act on amendments to certain laws of Ukraine on the status of village leaders and town governors ${ }^{9}$ was adopted. The law has improved the functioning of the institution of ULC head, the legal status of the head has been specified, and their powers and forms of subordination and accountability towards the community and the local council of the corresponding ULC have been defined. The law defined the notion of head district by introducing amendments to the Act on local government; the Act on amendments to certain laws of Ukraine on acquiring the powers of village leaders, town governors and city mayors ${ }^{10}$ was adopted, amending the Acts on local government and on local elections concerning the regulation of acquiring powers of village leaders, town governors and city mayors;

- The Cabinet of Ministers of Ukraine adopted a resolution ${ }^{11}$ on the system of remuneration of officials of local government bodies providing for: a significant increase of official salaries of local government officials, linked to the official salaries of civil servants; a renewal of allowances in village and town councils and their executive bodies for outstanding work achievements; systematising wages in village and town councils and their executive bodies representing ULCs; clarification as regards bonuses, and the establishment of an allowance system;

8 On amendments to certain laws of Ukraine on the peculiarities of the voluntary consolidation of local communities located in neighbouring areas: Act of 14 March 2017, № 1923-VIII, Official website of the Verkhovna Rada of Ukraine (Electronic source) - Information source: http://zakon2.rada.gov.ua/laws/show/1923-19.

9 On amendments to certain laws of Ukraine on the status of village leaders and town governors: Act of 9 February 2017, № 1848-VIII, Official website of the Verkhovna Rada of Ukraine (Electronic source) - Information sorce: http://zakon2.rada.gov. ua/laws/show/1848-19.

10 On amendments to certain laws of Ukraine on acquiring the powers of village leaders, town governors and city mayors: Act of 9 February 2017, № 1850-VIII, Official website of the Verkhovna Rada of Ukraine (Electronic source) - Information source: http://zakon2.rada.gov.ua/laws/show/1850-19.

11 On amendments to the resolution of the Cabinet of Ministers of Ukraine of 9 March 2006, № 268 and recognition of certain resolutions of the Cabinet of Ministers of Ukraine as invalid: Resolution of the Cabinet of Ministers of Ukraine of 24 May 2017, № 353, Government’s website (Electronic source) - Information source: http:// www.kmu.gov.ua/control/uk/cardnpd?docid=250014893. 
- The Cabinet of Ministers of Ukraine adopted an ordinance on the approval of the list of capable united local communities, in which the first elections of members of village, town and city councils as well as village leaders, town governors and city mayors took place in $2016^{12}$. The Government approved a list of capable united local communities for the regulatory and legal support for the transition to direct inter-budget relations with the State Budget of Ukraine of the united communities, in which the first local elections took place in 2016;

- On 6 June 2017, the act on amendments to the Act on the state budget of Ukraine for 2017" (regarding the provision of the financing of local elections $)^{13}$, which regulates the financial provision of local elections, including the first local elections in united local communities, was adopted;

- On 9 February 2017, the Verkhovna Rada of Ukraine adopted the Act on the service in local government bodies. It introduces fundamentally new principles of service in local government bodies and creates legal grounds for the regulation of the status of a local government body official; enhanced prestige of and equal access to services in local government bodies; promotion of career development; a new model of salary payment; the implementation of mechanisms for preventing corruption; enhanced social and financial protection of employees, etc. Measures have been taken to improve the institutional support for the decentralisation reform, too. In particular, the Central Office of Reforms has been established as a permanent advisory body to the Cabinet of Ministers of Ukraine in charge of organising and coordinating the implementation of reforms at an adequate level, in particular, regarding the planning of appropriate measures, monitoring and analysis of the status of their implementation ${ }^{14}$.

The Central Office of Reforms will interact with regional offices and field offices for decentralisation support in education, health care, spatial planning, culture, social protection and other areas. In each region, local

12 On the approval of the list of capable united local communities in which the first elections of members of village, town and city councils as well as village leaders town governors and city mayors took place in 2016: Order of the Cabinet of Ministers of Ukraine of 24 May 2017, № 348-p, Government's website (Electronic source) Information source: http://www.kmu.gov.ua/control/uk/cardnpd?docid=250014874.

13 Draft act on amendments to Act on the 2017 state budget(regarding provision of financing for local elections), Official website of the Verkhovna Rada of Ukraine (Electronic source) - Information source: http://w1.c1.rada.gov.ua/pls/zweb2/webproc4_1?pf3511=61760.

14 On creation of the Office of Reforms: Resolution of the Cabinet of Ministers of Ukraine of 11 October 2016, № 768, Official website of the Verkhovna Rada of Ukraine (Electronic resource) - Information source: http://zakon2.rada.gov.ua/laws/show/7682016-п. 
government development centres are established, which will coordinate the implementation of the decentralisation reform at the regional level.

The opening of the Central Office and regional centres takes place within the framework of the implementation of the programme for the improvement of rights and opportunities for Ukraine at the local level, accountability and development "U-LEAD with Europe" funded by the EU and some European countries. At the end of 2016, the Association of United Local Communities was established, with such tasks as co-operating with executive authorities at the local and national level, advocating the interests of the members of the Association and providing them with services and partnerships as well as coordinating joint efforts with all parties concerned. As of April 2017, the Association of United Local Communities brought together 62 local government bodies from 20 regions.

The above information allows us to conclude that the process of forming united local communities in Ukraine is rather dynamic and significant steps were taken in 2017 to improve the legislative and regulatory support of the creation and development of ULC.

At the same time, there are a number of unresolved problems, both strategic and operational, posing risks for a successful ongoing reform implementation. In particular, we should note the following problematic issues:

1) The development of long-term plans for the formation of the territories of district communities has not been completed and ex post changes are constantly made in the ULCs that have gone through the consolidation procedure and want to hold the first local elections and receive additional financial resources and administrative powers.

2) It is necessary to focus efforts on the continuous provision of financial state support for voluntary consolidation of territorial communities.

3) Generally, the process of the establishment of united local communities is not properly supported, and sometimes encounters resistance from district administrations, local councils and local elites.

4) The issue of optimal distribution of powers between local government bodies and executive authorities is not regulated in general, and, in particular, the distribution of functions and powers between local councils of ULCs and district administrations and district councils in the territory where ULCs are established.

5) There is no proper assistance for staff of local government bodies of united local communities and local self-government officials lack qualifications needed to perform new functions.

6) It is necessary to improve the implementation of mechanisms for monitoring the legitimacy of decisions of local government bodies and the quality of the provision of administrative and social services to the public. 
Any successful implementation of the reform of the local power organisation and local government on the basis of decentralisation in the future requires further work on improving the legislative and regulatory support of the reform. In particular, it is necessary to:

- Resume work on the draft law on amendments on decentralisation to the Constitution of Ukraine, which should improve the constitutional basis for the functioning of a new system of local power organisation and the system of the administrative and territorial structure of the state;

- Adopt the basic Act on the administrative and territorial structure of Ukraine, which will define the state policy principles in this area, the construction of a new administrative and territorial structure, unified requirements and criteria for administrative and territorial units of all levels, clear procedures for the formation and liquidation of administrative and territorial units, the procedure for setting and changing their boundaries, etc.;

- Prepare and adopt a new version of the Act on local government in Ukraine, improving the support of the functioning of the entire local government at various levels of administration, redistribution of powers in the system of local government bodies and between local government bodies and state bodies of executive power;

- Adopt the Act on the local referendum, since the legal mechanism for conducting a local referendum as a form of solving local issues by the direct expression of will of the local community was eliminated with the adoption of the Act on all-Ukrainian referendum in 2012;

- Amend the Act on cooperation of local communities as regards the introduction of the procedure for the adhesion of local communities to existing cooperation agreements;

In summary, it is worth noting that the reform of local government opens significant prospects for ensuring its ability to solve local issues independently, in particular, to increase the role of citizens and their influence on the process of the adoption and implementation of decisions on ensuring the conditions for social and economic development of society. When carried out, the reform will lead to the further democratisation of social relations because rather than supporting the separation of the country it creates opportunities for the development of the whole state space based on the priority of powers of local communities as a source of municipal, independent power of the state authorities. Finally, it will offer further opportunities to conduct the democratisation process from the bottom up. 


\section{Bibliography}

Decree of the President of Ukraine of 7 December 2016, № 545/2016, official website of the Verkhovna Rada of Ukraine (Electronic source) - Information source: http://zakon3.rada.gov.ua/laws/show/545/2016.

Order of the Cabinet of Ministers of Ukraine of 22 September 2016, № 688-p, website of the Government (Electronic source) - Information source: http://www. kmu.gov.ua/control/ru/cardnpd?docid=249350402.

Resolution of the Cabinet of Ministers of Ukraine of 8 September 2016, № 601, website of the Government (Electronic source) - Information source: http:// www.kmu.gov.ua/control/uk/cardnpd?docid $=249308591$.

On amendments to certain Ukrainian acts of law on voluntary adhesion of local communities: act of 9 February 2017, № 1851-VIII, official website of the Verkhovna Rada of Ukraine (Electronic source) - Information source: http:// zakon2.rada.gov.ua/laws/show/1851-19.

On amendments to certain Acts on the peculiarities of the voluntary consolidation of local communities located in neighbouring areas: Act of 14 March 2017, № 1923-VIII, official website of the Verkhovna Rada of Ukraine (Electronic source) - Information source: http://zakon2.rada.gov.ua/laws/show/1923-19.

On amendments to certain Acts on the status of village leaders and town governors: Act of 9 February 2017, № 1848-VIII, official website of the Verkhovna Rada of Ukraine (Electronic source) - Information source: http://zakon2.rada. gov.ua/laws/show/1848-19.

On amendments to certain Acts on acquiring the powers of village leaders, town governors and city mayors: Act of 9 February 2017, № 1850-VIII, official website of the Verkhovna Rada of Ukraine (Electronic source) - Information source: http://zakon2.rada.gov.ua/laws/show/1850-19.

On amendments to the resolution of the Cabinet of Ministers of Ukraine of 9 March 2006,r № 268 and recognition of certain resolutions of the Cabinet of Ministers of Ukraine as invalid: the resolution of the Cabinet of Ministers of Ukraine of 24 May 2017, № 353, website of the Government (Electronic source) - Information source: http://www.kmu.gov.ua/control/uk/cardnpd?docid=250014893.

Draft act on amendments to the act on the state budget for 2017 (regarding provision of financing of local elections), official website of the Verkhovna Rada of Ukraine (Electronic source) - Information source: http://w1.c1.rada.gov.ua/ pls/zweb2/webproc4_1?pf3511=61760.

Resolution of the Cabinet of Ministers of Ukraine of 11 October 2016, № 768, official website of the Verkhovna Rada of Ukraine (Electronic resource) Information source: http://zakon2.rada.gov.ua/laws/show/768-2016-п.

\section{Abstract}

The article describes the process of several years of local government reforms in Ukraine initiated in 2015 and its results. The basic objectives of these reforms are decentralisation, equipping local communities with instruments of local democracy as well as, guaranteeing affordable and good-quality public services. The reform process is intense. The summary of the article shows the problems and deficiencies related to the reform that still need to be resolved. 
Keywords: reform of local government in Ukraine, united local communities in Ukraine, decentralisation

\section{Powstawanie skonsolidowanych społeczności lokalnych: warunki i problemy}

Streszczenie

Artykuł opisuje proces kilkuletnich reform samorządu terytorialnego na Ukrainie zapoczątkowanych w 2015 r. oraz jego rezultaty. Podstawowe założenia tych reform to decentralizacja, wyposażenie wspólnot lokalnych w instrumenty demokracji lokalnej, zagwarantowanie niedrogich oraz dobrej jakości usług publicznych. Proces reform jest intensywny. W podsumowaniu artykułu ukazano problemy pojawiające się przy wprowadzaniu reformy, które trzeba jeszcze rozwiązać.

Słowa kluczowe: reforma samorządu terytorialnego na Ukrainie, wspólnoty lokalne na Ukrainie, decentralizacja 